Daniela Wybrańczyk

\title{
Instytucja wysłuchania małoletniego przed sądem w sprawach go dotyczących
}

\author{
Institution of hearing a minor in court in matters that concern him/her
}

\begin{abstract}
In the article premises for hearing a minor are presented, as well as organizational issues related to it. The analysis of the provisions in force leads to the conclusion that the role a psychologist plays in a hearing of a minor is still not adequately appreciated. There are no regulations providing for the obligatory participation of a psychologist in a hearing of a child. It is therefore necessary to change the provisions in this respect, so as to determine the competence of a psychologist in a hearing, establish whether a hearing is held by a single-member court or a court in collegiate composition, where a hearing takes place: in the course of divorce proceedings or before the appeal court. Moreover, the issue of frequency of hearing a minor should be clarified.
\end{abstract}

Keywords: courts, psychologist, children's rights

\begin{abstract}
W artykule przedstawiono przesłanki wysłuchania małoletniego oraz kwestie organizacyjne z tym związane. Analiza obowiązujących przepisów prowadzi do wniosku, że rola psychologa w wysłuchaniu małoletniego nie jest należycie doceniana. Brakuje regulacji przewidujących jego obligatoryjny udział w wysłuchaniu dziecka. Konieczna jest zmiana przepisów poprzez m.in. określenie kompetencji psychologa w wysłuchaniu oraz przesądzenie tego, czy w sytuacji, gdy wysłuchanie ma miejsce w czasie trwania postępowania rozwodowego bądź przed sądem odwoławczym, dokonuje go sąd jednoosobowo, czy też sąd w składzie kolegialnym. Ponadto powinna zostać doprecyzowana kwestia częstotliwości wysłuchania małoletniego.
\end{abstract}

Słowa kluczowe: sądy, psycholog, prawa dziecka

doktorantka -

Uniwersytet Śląski w Katowicach, Wydział Prawa i Administracji, KATOWICE, POLSKA • daniela.wybranczyk@gmail.com • https://orcid.org/0000-0001-6961-5474

\section{Wprowadzenie}

Ustawa z dnia 6 listopada 2008 r. o zmianie ustawy - Kodeks rodzinny i opiekuńczy oraz niektórych innych ustaw (Dz.U. nr 220, poz. 1431) wprowadziła do polskiego prawa instytucję wysłuchania małoletniego ${ }^{1}$. Wysłuchanie to jest wyrazem realizacji zasady bezpośredniości i daje okazję do ujawnienia ewentu-

1 W dalszych wywodach pojęcie małoletniego będzie stosowane zamiennie z pojęciem dziecka. 
alnych nieprawidłowości związanych z wykonywaniem praw dziecka ${ }^{2}$. Stanowi ono jednocześnie gwarancję ochrony interesów małoletniego ${ }^{3}$.

Wobec planowanej nowelizacji Kodeksu rodzinnego i opiekuńczego (rządowy projekt ustawy z dnia 27 lutego 2019 r. o zmianie ustawy - Kodeks rodzinny i opiekuńczy oraz niektórych innych ustaw, druk sejmowy nr 3254; dalej: rządowy projekt nowelizacji Kodeksu rodzinnego i opiekuńczego z 2019 r.) ${ }^{4}$ zasadne jest omówienie instytucji wysłuchania małoletniego z jednoczesnym zwróceniem uwagi na potrzebę doprecyzowania przepisów regulujących tę instytucję. Obecnie (luty 2020 r.) w związku z zakończeniem VIII kadencji Sejmu prace nad projektem zostały przerwane, niemniej jednak można przypuszczać, że zostaną wznowione. W przeciwnym razie poczynione uwagi mogą stanowić podstawę do dyskusji na temat udoskonalenia przepisów dotyczących wysłuchania dziecka ${ }^{5}$. Do podstawowych kwestii wymagających zmiany należy określenie pozycji biegłego psychologa w wysłuchaniu dziecka oraz przesądzenie tego, kto dokonuje tego wysłuchania.

Nie budzi wątpliwości to, że wysłuchania małoletniego dokonuje sąd. Pełna realizacja zasady ochrony dobra dziecka ${ }^{6}$ wymaga jednak współudziału psycho-

2 J. Bodio, Status dziecka jako uczestnika postępowania nieprocesowego, Warszawa 2019, s. 409.

3 O genezie wysłuchania (w postępowaniu opiekuńczym) zob. A. Kallaus, Udział osoby małoletniej w postępowaniu opiekuńczym, Poznań 2015, s. 96. Zob. też W. Stojanowska [w:] Nowelizacja prawa rodzinnego na podstawie ustaw z 6 listopada $2008 \mathrm{r}$. i 10 czerwca 2010 r. Analiza. Wykładnia. Komentarz, red. W. Stojanowska, Warszawa 2011, s. 343 i n. W publikacji przedstawiono szczegółowy opis prac komisji sejmowej, w tym ewolucję przepisów dotyczących wysłuchania małoletniego. Autorka omówiła również problematykę wysłuchania dziecka w postępowaniu sądowym przed nowelizacją z 6 listopada 2008 r. (s. 347).

4 https:/www.rpo.gov.pl/sites/default/files/Poselski\%20projekt\%20nowelizacji\%20 KRO.pdf [dostęp 1 lutego 2020 r.].

5 Projekt wpłynął do Sejmu 27 lutego 2019 r. i został skierowany do pierwszego czytania na posiedzeniu Sejmu. Odbyło się ono 26 kwietnia 2019 r. Następnie projekt przekazano Komisji Nadzwyczajnej do spraw zmian w kodyfikacjach. 14 czerwca 2019 r. przedstawiono sprawozdanie podkomisji, a 2 lipca 2019 r. sprawozdanie komisji. W tym czasie wprowadzono autopoprawkę do projektu z 9 kwietnia 2019 r. (druk sejmowy nr 3254-A, http://orka.sejm.gov.pl/Druki8ka.nsf/0/6FB2A336AEFAC630C12583D80 0547403/\%24File/3254-A.pdf [dostęp 1 lutego 2020 r.]), po czym oba projekty zastąpiono rządowym projektem ustawy o zmianie ustawy - Kodeks rodzinny i opiekuńczy, ustawy - Kodeks postępowania cywilnego oraz ustawy o kosztach sądowych w sprawach cywilnych z dnia 2 lipca 2019 r. (druk sejmowy nr 3564, http://orka.sejm.gov. pl/Druki8ka.nsf/0/4E56AF4D3D7E47D9C125842C002CE0CF/\%24File/3564.pdf [dostęp 1 lutego 2020 r.]). Ten ostatni projekt nie wprowadził jednak zmian w zakresie przedstawionej propozycji nowelizacji art. $216^{1}$ i 576 Kodeksu postępowania cywilnego.

$6 \quad$ Pojęcie dobra dziecka nie zostało przez ustawodawcę wprost zdefiniowane. Przyjęto, że powinno być ono interpretowane indywidualnie w poszczególnych przypad- 
loga, którego rola nie została odpowiednio zaznaczona w obowiązujących przepisach. Tymczasem Europejski Trybunał Praw Człowieka (dalej: ETPC) w szeregu spraw rodzinnych orzekł, że sądy krajowe powinny przeprowadzić ocenę trudnej kwestii, jaką jest dobro dziecka, w oparciu o opinię psychologiczną oraz że dziecko, jeżeli jest to możliwe i zgodne z jego wiekiem oraz poziomem dojrzałości, powinno zostać wysłuchane przez psychologa i sąd w kwestiach go dotyczących ${ }^{7}$.

W odpowiedzi na Interpelację nr 5708 w sprawie przeciwwskazań do przeprowadzania wysłuchań dzieci w oparciu o art. $216^{1}$ k.p.c. i art. $576 \$ 2$ k.p.c. ${ }^{8}$ zasadnie zwrócono uwagę, że kwestia rozeznania stopnia rozwoju umysłowego małoletniego oraz stopnia jego dojrzałości i w konsekwencji oceny rozsądności jego wypowiedzi może uzasadniać powołanie do wysłuchania osoby dysponującej wiedzą specjalistyczną.

Artykuł $216^{1} \$ 1$ ustawy z dnia 17 listopada 1964 r. - Kodeks postępowania cywilnego (t.j. Dz.U. 2020, poz. 288, ze zm.; dalej: k.p.c.), stanowiący podstawę do wysłuchania małoletniego w postępowaniu procesowym, jest normą ogólną i formalnie odnosi się do każdej sprawy, która dotyczy dziecka. W praktyce największe znaczenie ma jednak w sprawach małżeńskich, w których rozstrzyga się o władzy rodzicielskiej i kontaktach (np. w sytuacji rozwodu), względnie w sprawach dotyczących pochodzenia dziecka lub rozwiązania przez sąd przysposobienia. Odpowiednikiem art. $216^{1} \$ 1$ k.p.c. w postępowaniu nieprocesowym jest art. $576 \$ 2$ k.p.c.

Przyjęte w innych państwach rozwiązania prawne w zakresie udziału małoletniego w sprawach go dotyczących również zapewniają dziecku możliwość wypo-

kach. Mimo to w doktrynie i orzecznictwie wypracowano pomocnicze definicje tego pojęcia. Ich wspólną cechą jest definiowanie dobra dziecka przy respektowaniu jego fundamentalnego znaczenia $\mathrm{w}$ systemie preferencji społecznych, co wywodzi się z podstawowej w prawie rodzinnym dyrektywy nakazującej uwzględniać interes dziecka jako prymarny przy kształtowaniu stosunków rodzinnych. Zob.: S. Kołodziejski, Dobro wspólnych małoletnich dzieci - jako przesłanka odmowy orzeczenia rozwodu, „Palestra” 1965, nr 9, s. 30; A. Łapiński, Ograniczenia władzy rodzicielskiej w polskim prawie rodzinnym, Warszawa 1975, s. 131; W. Stojanowska, Rozwód a dobro dziecka, Warszawa 1979, s. 27; Z. Radwański, Pojęcie i funkcja „dobra dziecka” w polskim prawie rodzinnym i opiekuńczym, „Studia Cywilistyczne” 1981, t. XXXI, s. 9; A. Olejniczak, Materialnoprawne przesłanki udzielenia rozwodu, Poznań 1980, s. 52; wyrok TK z dnia 28 kwietnia 2003 r., K 18/02, OTK 2003, nr 4, poz. 32; uchwała SN z dnia 14 lutego 1955 r., I CO 83/54, OSNCK 1955, nr 3, poz. 52; uchwała SN z dnia 18 marca 1968 r., III CZP 70/66, OSNC 1968, nr 5, poz. 77 (pkt III).

7 Zob.: wyrok z dnia 13 lipca 2000 r. w sprawie nr 25735/94 Elsholz przeciwko Niemcom [w:] Nowy Europejski Trybunał Praw Człowieka. Wybór orzeczeń 1999-2004, oprac. M.A. Nowicki, Kraków 2005, s. 1301; wyrok ETPC z dnia 8 lipca 2003 r. w sprawie nr 31871/96 Sommerfeld przeciwko Niemcom [w:] Nowy Europejski Trybunat Praw Człowieka. Wybór orzeczeń 1999-2004, oprac. M.A. Nowicki, Kraków 2005, s. 1311.

8 http://www.sejm.gov.pl/Sejm8.nsf/InterpelacjaTresc.xsp?key=1A88F379 [dostęp 1 lutego 2020 r.]. 
wiedzenia się. W Finlandii małoletni wpływa na przebieg postępowania poprzez wyrażenie swoich życzeń i opinii, co reguluje fińska ustawa o opiece nad dziećmi z 2007 r. ${ }^{9}$ Zgodnie z jej $\$ 22$ dziecku wyznacza się kuratora w miejsce przedstawiciela prawnego. Zadaniem kuratora jest m.in. stworzenie małoletniemu gwarancji wysłuchania. Z kolei $\$ 24$ stanowi, że pracownicy socjalni są zobowiązani do nadzorowania i wspierania dzieci w zakresie urzeczywistniania ich praw do wysłuchania, mogą również podejmować kroki zmierzające do ustanowienia kuratora.

Zgodnie z art. 315 bis włoskiego kodeksu cywilnego z 1942 r. ${ }^{10}$ dziecko, które skończyło 12 lat, a także jeśli jest młodsze, ale jest zdolne do rozeznania, ma prawo do bycia wysłuchanym we wszystkich sprawach i procedurach, które go dotyczą. W określonych przypadkach przepisy szczególne wyznaczają inny próg wiekowy (zob. np. art. 371).

Artykuł 3.164 ust. 1 litewskiego kodeksu cywilnego z 2000 r. $^{11}$ stanowi, że dziecko, które jest w stanie wyrazić swoje poglądy, we wszystkich sprawach go dotyczących powinno być wysłuchane. Jeżeli małoletni uważa, że rodzice naruszają jego prawa, ma możliwość obrony z pomocą państwowego organu ochrony dziecka, a od 14 roku życia także prawo do sądu (ust. 2). Zgodnie $\mathrm{z}$ art. 3.178 ust. 1 tego kodeksu w sporach dotyczących dzieci jest wymagany obligatoryjny udział organu państwowego w celu ochrony praw dziecka.

Jak wynika z art. 57 kodeksu rodzinnego Federacji Rosyjskiej z 1995 r. ${ }^{12}$, dziecko ma prawo do wyrażenia swojej opinii przy podejmowaniu decyzji w sprawie rodzinnej mającej wpływ na jego interesy, a także do bycia wysłuchanym $\mathrm{w}$ trakcie postępowania sądowego lub administracyjnego. Uwzględnienie opinii dziecka, które ukończyło 10 lat, jest obowiązkowe, chyba że jest to sprzeczne z jego interesami. W określonych przypadkach, np. dotyczących zmiany imienia i nazwiska, organy opiekuńcze lub sąd mogą podjąć decyzję wyłącznie za zgodą dziecka, które ukończyło 10 lat (art. 59).

\section{Przesłanki wysłuchania małoletniego}

Zgodnie z powołanym wyżej art. $216^{1} \$ 1$ zdanie pierwsze k.p.c. (por. też art. 576 $\$ 2$ k.p.c.) w sprawach dotyczących dziecka sąd wysłuchuje je, jeżeli jego rozwój

9 Lastensuojelulaki, https://www.finlex.fi/en/laki/kaannokset/2007/en20070417 [dostęp 1 lutego 2020 r.].

10 Codice civile, https://www.brocardi.it/codice-civile [dostęp 1 lutego 2020 r.].

11 Lietuvos Respublikos civilinio kodekso patvirtinimo, įsigaliojimo ir ịgvendinimo ịstatymas. Civilinis kodeksas, https://e-seimas.lrs.lt/portal/legalAct/lt/TAD/TAIS.107687 [dostęp 1 lutego 2020 r.].

12 Семейный Кодекс Российской Федерации, http://www.consultant.ru/document/ cons_doc_LAW_8982 [dostęp 1 lutego 2020 r.]. 
umysłowy ${ }^{13}$, stan zdrowia ${ }^{14}$ i stopień dojrzałości na to pozwala. Przesłanki dopuszczające wysłuchanie małoletniego określone w ten sposób sprawiają jednak, że granica wieku dziecka, po której przekroczeniu jest dopuszczalne jego wysłuchanie, wciąż budzi kontrowersje ${ }^{15}$.

Powołane przepisy ściśle wiążą się z regulacją materialnoprawną wprowadzoną do Kodeksu rodzinnego i opiekuńczego nakazującą uwzględnienie stanowiska dziecka $w$ ważniejszych sprawach dotyczących jego osoby lub majątku (art. $95 \$ 4$ ustawy z dnia 25 lutego 1964 r. - Kodeks rodzinny i opiekuńczy, t.j. Dz.U. 2019, poz. 2086). Sprawa o rozwód w zakresie rozstrzygnięcia o władzy rodzicielskiej i kontaktach z dzieckiem jest tą, w której dziecko powinno zostać wysłuchane ${ }^{16}$. W praktyce wysłuchanie dziecka ma największe znaczenie w tych właśnie sprawach, dlatego też poniższe uwagi będą dotyczyć przede wszystkim postępowania o rozwód. Należy jednak zaznaczyć, że art. $216^{1} \S 1$ k.p.c. wobec braku posłużenia się sformułowaniem „w sprawach dotyczących osoby lub majątku dziecka", tak jak ma to miejsce w art. $576 \$ 2$ k.p.c., nie jest stosowany w odniesieniu do spraw o alimenty ${ }^{17}$.

13 Przy ocenie stopnia rozwoju umysłowego dziecka uwzględnia się zarówno kwestie jego etapu rozwojowego, jak i indywidualne odstępstwa od norm rozwojowych. Tak A. Czerederecka, Psychologiczne kryteria wystuchania dziecka w sprawach rodzinnych i opiekuńczych, ,Rodzina i Prawo” 2010, nr 14-15, s. 27.

14 Oceniając stan zdrowia dziecka, bierze się pod uwagę upośledzenia umysłowe, zaburzenia o podłożu neurologicznym, stany psychotyczne, zaburzenia zachowania oraz emocji, zaburzenia rozwoju psychicznego i zaburzenia związane z dolegliwościami somatycznymi. Nie można automatycznie zakładać, że nie jest możliwe bezpośrednie wysłuchanie dziecka ujawniającego zaburzenia rozwoju psychicznego. Tak ibidem, s. 33.

15 W odpowiedzi na interpelację nr 15737 w sprawie wysłuchań informacyjnych małoletnich i przyjaznych pokojów przesłuchań dzieci (http://www.sejm.gov.pl/Sejm8.nsf/InterpelacjaTresc.xsp?key=7DE00E7C [dostęp 1 lutego 2020 r.]) zwrócono uwagę, że ustawodawca, odstępując od ścisłego określenia wieku małoletniego w przepisach art. $216^{1}$ $\$ 1$ k.p.c., wprowadził kryteria ocenne, odwołujące się do warunków i właściwości ściśle osobistych dziecka. W konsekwencji powołane przepisy są bardziej elastyczne od przepisów obowiązujących w procesie karnym. Wprowadzenie sztywnej granicy, np. 13 lat, raziłoby sztucznością. Jednocześnie w odpowiedzi na tę interpelację zaznaczono, że nie przewiduje się w postępowaniu pomocy psychologicznej po wysłuchaniu.

16 M. Domański, Orzekanie o pieczy naprzemiennej w wyrokach rozwodowych, „Prawo w Działaniu" 2016, nr 25, s. 132. Autor podaje, że w zbadanych przez niego sprawach w zakresie orzekania o pieczy naprzemiennej, a zatem w sprawach, w których poznanie preferencji dziecka jest istotne, instytucja wysłuchania małoletniego była właściwie martwa (s. 133).

17 Tak też: R. Zegadło, Dziecko w postępowaniach sądowych i administracyjnych, „Rodzina i Prawo" 2011, nr 19, s. 58; A. Zieliński [w:] Kodeks postępowania cywilnego. Komentarz, red. K. Flaga-Gieruszyńska, A. Zieliński, Warszawa 2019, s. 498, nb. 3; S. Cieślak [w:] Kodeks postępowania cywilnego. Komentarz. Art. 1-729, t. I, red. A. Góra-Błasz- 
Przed przystąpieniem do wysłuchania sąd ocenia, czy zachodzą przesłanki wysłuchania dziecka w kwestiach dotyczących jego osoby. Jeśli przesłanki te zachodzą, sąd wysłuchuje małoletniego z urzędu. Spełnienie przesłanek jest oceniane w świetle okoliczności sprawy w odniesieniu do konkretnego dziecka. Ze względu na to, że wysłuchanie małoletniego stanowi czynność procesową, zarówno o jego przeprowadzeniu, jak i o pominięciu decyduje sąd, a więc skład orzekający sądu, a nie jego przewodniczący ${ }^{18}$. W praktyce zdarzają się również wnioski pełnomocników stron o wysłuchanie dziecka. Najczęściej jednak pełnomocnicy zmierzają do wysłuchania małoletniego pośrednio, tj. poprzez zgłoszenie dowodu $\mathrm{z}$ opinii biegłych ${ }^{19}$. Rzadko są zgłaszane wnioski odnoszące się do sposobu czy miejsca wysłuchania ${ }^{20}$. W postępowaniu rozwodowym brakuje jednolitej praktyki w zakresie tego, czy przez pojęcie „sądu” użyte w art. $216^{1}$ k.p.c. należy rozumieć sędziego przewodniczącego (na podstawie „posiłkowego” stosowania art. $235 \$ 1$ k.p.c.), czy też sędziego wraz z ławnikami (zob. art. $47 \$ 2$ pkt 2 lit. a k.p.c. $)^{21}$. Do czasu ingerencji ustawodawcy należy przyjąć, że wysłuchania dokonuje sędzia przewodniczący, gdyż taka wykładnia odpowiada zasadzie ochrony

czykowska, Warszawa 2013, s. 595, nb. 2. Inaczej P. Telenga [w:] Kodeks postępowania cywilnego. Komentarz do art. 1-729, t. I, red. A. Jakubecki, Warszawa 2017, s. 399, nb. 2. Tak wyrok SN z dnia 13 grudnia 2003 r., SNO 35/13, LEX nr 1409019, Legalis nr 753861. O psychologicznych czynnikach warunkujących wysłuchanie dziecka zob. A. Czerederecka, Wystuchanie dziecka $w$ sadzie $w$ sprawach rodzinnych $i$ opiekuńczych - perspektywa psychologiczna [w:] Problemy jednostki i rodziny w obszarze stosowania prawa. Aspekty psychologiczne, red. D. Rode, Warszawa 2016, s. 111 i n. Marcin Cieśliński opowiada się za stosowaniem art. $216^{1}$ k.p.c. jedynie w sposób bezpośredni. Zob.: M. Cieśliński, Praktyka sądowa wystuchiwania małoletnich w postępowaniach cywilnych $w$ kontekście idei przyjaznego wystuchiwania dziecka (komunikat o wynikach badania), „Prawo w Działaniu” 2015, nr 24, s. 229; M. Cieśliński, Wysłuchanie dziecka w procesie cywilnym (art. 216 ${ }^{1}$ k.p.c.), „Przegląd Sądowy” 2012, nr 6, s. 64.

M. Cieśliński, Stanowisko sędziów na temat wystuchania małoletnich w postępowaniu cywilnym, „Prawo w Działaniu” 2017, nr 29, s. 143.

21 M. Cieśliński, Praktyka, op. cit., s. 226. Autor podaje, że modelem dominującym jest jednak wysłuchanie małoletniego jednoosobowo przez przewodniczącego, choć osobiście opowiada się za wysłuchaniem dziecka w składzie kolegialnym (s. 234). Stanisław Burdziej przedstawia postulaty dotyczące instytucji wysłuchania, wśród nich m.in. postulat doprecyzowania, że wysłuchania małoletniego dokonuje sędzia wyznaczony, ponieważ obecne sformułowanie „sąd” implikuje - w przypadku składów trzyosobowych - konieczność przeprowadzenia wysłuchania w gronie co najmniej trzech osób dorosłych, co jest stresujące dla dziecka, a także niepotrzebnie absorbuje orzeczników. S. Burdziej, Badanie idei przyjaznego wystuchania dziecka - raport $z$ analizy wywiadów pogłębionych. Opracowanie czastkowe w ramach projektu prowadzonego przez Instytut Wymiaru Sprawiedliwości pt. „Praktyka sądowa w zakresie wysłuchiwania małoletnich $w$ postępowaniach cywilnych $w$ kontekście idei przyjaznego wystuchiwania dziecka", Warszawa 2015, s. 16-17. 
dobra dziecka, którego nie powinno się narażać na niepotrzebny stres związany z wysłuchiwaniem przez kilka dorosłych osób.

Regulacje Kodeksu postępowania cywilnego dotyczące wysłuchania dziecka mają istotne znaczenie praktyczne. Znajdują umocowanie w art. 72 ust. 3 Konstytucji Rzeczypospolitej Polskiej z dnia 2 kwietnia 1997 r. (Dz.U. nr 78, poz. 483; dalej: Konstytucja) i art. 12 Konwencji o prawach dziecka przyjętej przez Zgromadzenie Ogólne Narodów Zjednoczonych 20 listopada 1989 r. (Dz.U. 1991, nr 120, poz. 526; dalej: Konwencja ${ }^{22}$. Artykuł 72 ust. 3 Konstytucji zobowiązuje jednak do uwzględnienia zdania dziecka jedynie w miarę możliwości, a przepis art. 12 ust. 1 Konwencji stanowi o wysłuchaniu dziecka, o ile jest ono zdolne do kształtowania własnych poglądów. Ocena wagi wypowiedzi odbywa się z uwzględnieniem wieku i dojrzałości małoletniego. Oznacza to, że obowiązek wysłuchania przez organy stanowiska dziecka nie ma skutku w postaci obowiązku każdorazowego uwzględnienia tego stanowiska $\mathrm{w}$ toku wydawania rozstrzygnięcia ${ }^{23}$. Jeśli jednak przesłanki wynikające $\mathrm{z}$ art. $216^{1} \$ 1$ zdanie pierwsze k.p.c. (odpowiednio $\mathrm{z}$ art. $576 \$ 2$ k.p.c.) są spełnione, sąd ma obowiązek wysłuchania dziecka ${ }^{24}$. Innymi słowy, instytucja wysłuchania dziecka jest instytucją względnie obligatoryjną ${ }^{25}$.

22 Nazywana jest „światową konstytucją praw dziecka”. Zob. A. Łopatka, Dziecko - jego prawa człowieka, Warszawa 2000, s. 19. Inicjatorem uchwalenia Konwencji była Polska, szerzej o tym zob. ibidem, s. 21 i n. Konwencja ta na tle innych traktatów praw człowieka ONZ została ratyfikowana przez największą liczbę państw (193). Tak Leksykon ochrony praw człowieka. 100 podstawowych pojęć, red. M. Balcerzak, S. Sykuna, Warszawa 2010, s. 82. Zob. też art. 3 i 6 Europejskiej konwencji o wykonywaniu praw dzieci sporządzonej w Strasburgu dnia 25 stycznia 1996 r. (Dz.U. 2000, nr 107, poz. 1128). W kontekście istotności wysłuchania zob. art. 23, 41 i 42 rozporządzenia Rady (WE) nr 2201/2003 z dnia 27 listopada 2003 r. dotyczącego jurysdykcji oraz uznawania i wykonywania orzeczeń w sprawach małżeńskich oraz w sprawach dotyczących odpowiedzialności rodzicielskiej, uchylającego rozporządzenie (WE) nr 1347/2000 (Dz.Urz. UE L 338 z 23.12.2003, s. 1; zwanego rozporządzeniem Bruksela II bis). Szerzej o źródłach prawa dziecka do wypowiedzi w regulacjach międzynarodowych i wspólnotowych zob. K. Borkowska, Prawo dziecka do wypowiedzi w prawie międzynarodowym i krajowym, „Rodzina i Prawo” 2011, nr 19, s. 67 i n.

23 Wyrok NSA z dnia 29 sierpnia 2018 r., II OSK 1041/18, LEX nr 2553581, Legalis nr 1825975.

24 K. Flaga-Gieruszyńska, Ochrona dobra dziecka w postępowaniu odrębnym w sprawach małżeńskich [w:] Ochrona strony słabszej stosunku prawnego. Księga jubileuszowa ofiarowana Profesorowi Adamowi Zielińskiemu, red. M. Boratyńska, Warszawa 2016, s. 912; M. Cieśliński, Wystuchanie, op. cit., s. 66. M. Cieśliński zaznacza też, że w sytuacjach trudnych, zwłaszcza gdy rozwój umysłowy i stopień dojrzałości dziecka budzą uzasadnione wątpliwości, sąd powinien dopuścić dowód $\mathrm{z}$ opinii biegłego, np. z zakresu psychologii, w celu stwierdzenia podstaw do wysłuchania.

25 H. Ciepła [w:] Nowelizacje Kodeksu rodzinnego i opiekuńczego z komentarzem, Warszawa 2010, s. 21; W. Stojanowska [w:] Nowelizacja, op. cit., s. 352. 
W pierwotnym brzmieniu art. 576 k.p.c. stanowił jedynie o wysłuchaniu przedstawiciela ustawowego osoby, której dotyczy postępowanie, oraz - w przypadkach ważniejszych - osób bliskich. Mimo braku dosłownego wskazania dziecka w przywołanym przepisie w orzecznictwie była formułowana zasada jego wysłuchania, od której odstąpienie powinno następować jedynie w wyjątkowych sytuacjach. Następnie przepis ewoluował i obecnie wysłuchanie dziecka zostało uwarunkowane trzema przesłankami występującymi łącznie. Analogiczne przesłanki wynikają $\mathrm{z}$ mającego zastosowanie w postępowaniu procesowym art. $216^{1}$ k.p.c. Uwzględnienie życzeń dziecka jest z kolei uwarunkowane: okolicznościami, rozwojem umysłowym dziecka, stanem jego zdrowia i stopniem dojrzałości ${ }^{26}$.

Wysłuchanie umożliwia poznanie przez sąd małoletniego, jego sytuacji i punktu widzenia w rozpatrywanej sprawie. Oceny przesłanek wysłuchania sąd powinien dokonywać $\mathrm{w}$ świetle zasady dobra dziecka ${ }^{27}$. W postępowaniu rozwodowym wysłuchanie dziecka ma przede wszystkim na celu poznanie jego preferencji co do sposobu wykonywania władzy rodzicielskiej, określenia miejsca jego pobytu i ustalenia kontaktów z rodzicami. Działanie na podstawie art. $216^{1} \$ 1$ k.p.c. nie może prowadzić do omijania zakazu przesłuchiwania w procesie o rozwód w charakterze świadków zstępnych stron, którzy nie ukończyli lat 17 (art. 430 k.p.c.). Jednocześnie należy podkreślić, że w przeciwieństwie do przesłuchania świadka wysłuchanie dziecka nie jest traktowane jako dowód. Niemniej jednak funkcja wysłuchania jest podobna do dowodu, ponieważ służy zebraniu przez sąd wiadomości o faktach wchodzących w skład podstawy faktycznej sprawy i w konsekwencji może decydować o treści orzeczenia $^{28}$. Trzeba też uważać, aby wysłuchanie małoletniego nie wciągnęło go w konflikt rodziców. Z psychologicznego punktu widzenia dzieci uwikłane w konflikt rodziców, które obronnie identyfikują się z jednym z nich, nie powinny być wysłuchiwane, ponieważ nie mają własnej (autonomicznej) perspektywy

${ }^{26}$ Zob. J. Słyk, Aspekty prawne wystuchania dziecka w postępowaniu cywilnym, „Dziecko Krzywdzone. Teoria, Badania, Praktyka” 2015, nr 4, s. 17-18. Autor dokonuje też przeglądu stanowisk opowiadających się za obligatoryjnością i przeciw obligatoryjności wysłuchania. Ibidem, s. 19-20. Zob. też postanowienie SN z dnia 1 października 1998 r., I CKN 825/98, LEX nr 1108442, Legalis nr 355867.

J. Pawliczak [w:] Kodeks rodzinny i opiekuńczy. Komentarz, t. 5, red. K. Osajda, Warszawa 2017, s. 728, nb. 38.

Wysłuchanie określa się jako pomocniczą instytucję procesową o charakterze techniczno-procesowym. Ponadto wysłuchanie dziecka - w przeciwieństwie do składania przez nie zeznań w charakterze świadka - nie jest ukierunkowane na relację o faktach, ale na przedstawienie ocen. M. Cieśliński podaje, że wysłuchanie dziecka stanowi czynność procesową o szczególnym charakterze, mającą zapewnić dziecku podmiotowość procesową bez przyznawania mu zdolności procesowej. M. Cieśliński, Wystuchanie, op. cit., s. 64 . 
sytuacji rodzinnej ${ }^{29}$. W wytycznych Komitetu Ministrów Rady Europy dotyczących przyjaznego dzieciom wymiaru sprawiedliwości podkreślono, że dziecko nie powinno być zmuszane do wypowiadania się $\mathrm{w}$ sprawie ${ }^{30}$.

Wysłuchanie odbywa się poza salą posiedzeń sądowych - może mieć miejsce w pokoju urządzonym odpowiednio do tego celu. W wysłuchaniu dziecka nie biorą udziału rodzice ani ich pełnomocnicy. Zgodnie $\mathrm{z} \$ 186$ rozporządzenia Ministra Sprawiedliwości z dnia 18 czerwca 2019 r. Regulamin urzędowania sądów powszechnych (Dz.U. poz. 1141) wysłuchanie małoletniego dziecka przeprowadza się, o ile jest to możliwe, $w$ przeznaczonym i przystosowanym do tego celu pomieszczeniu. Jeśli nie ma takiego pomieszczenia w siedzibie sądu, można przeprowadzić wysłuchanie także $\mathrm{w}$ spełniającym te warunki pomieszczeniu znajdującym się poza budynkiem sądu. $Z$ wysłuchania małoletniego sporządza się notatkę urzędową ${ }^{31}$, co wyklucza obecność protokolanta przy wysłuchaniu.

$29 \mathrm{Na}$ to, aby unikać zadawania sugestywnych pytań, zwraca też uwagę Joanna Zajączkowska. J. Zajączkowska, Głos dziecka na wokandzie - o instytucji wystuchania małoletniego, „Palestra” 2013, nr 7-8, s. 63. Z odpowiedzi na interpelację nr 5708 wynika, że pytania zadawane małoletniemu powinny być postawione $\mathrm{w}$ taki sposób, aby to sędzia mógł sam wywnioskować z wypowiedzi dziecka o jego opinii oraz życzeniach. Podkreślono tam, że nie można dopuścić, aby pytania sędziego implikowały odpowiedzi małoletniego.

30 Wytyczne Komitetu Ministrów Rady Europy w sprawie wymiaru sprawiedliwości przyjaznego dzieciom przyjęte przez ten Komitet dnia 17 listopada 2010 r. wraz z uzasadnieniem, s. 28, pkt 46, https://publications.europa.eu/pl/publication-detail/-/ publication/5f031e5d-9f09-11e5-8781-01aa75ed71a1 [dostęp 1 lutego 2020 r.]. Jednocześnie $\mathrm{w}$ wytycznych znalazło się zalecenie konsultowania $\mathrm{z}$ dzieckiem sposobu, w jaki chce zostać wysłuchane (s. 28, pkt 44). Wytyczne zawierają też zalecenia dotyczące organizacji postępowań, środowiska i języka przyjaznego dziecku. Jak zaznaczono w uzasadnieniu wytycznych, "procedury w zakresie wysłuchania dzieci powinny być przejrzyste, informatywne, dobrowolne, adekwatne, przyjazne dziecku, integracyjne, prowadzone przez wyszkolonych pracowników, bezpieczne, powinny dbać o poszanowanie, a także uwzględniać ryzyko i cechować się odpowiedzialnością" (s. 85). Powyższe wytyczne nie są jednak instrumentem wiążącym, opierają się na obowiązujących normach międzynarodowych, europejskich i krajowych, a ich „[m]otywem przewodnim [...] jest dobro dziecka” (s. 44).

31 Joanna Plewka wadliwie podaje, że z wysłuchania sporządzało się protokół na podstawie art. 157 k.p.c., wysłuchanie dziecka nie jest bowiem przeprowadzane na posiedzeniu jawnym. J. Plewka, Instytucja wystuchania małoletniego w świetle unormowań prawnych kodeksu postępowania cywilnego [w:] Tendencje prawa materialnego i procesowego cywilnego, red. E. Marszałkowska-Krześ, Wrocław 2017, s. 55. Zob. też J. Ignaczewski [w:] Władza rodzicielska i kontakty z dzieckiem, red. J. Ignaczewski, Warszawa 2019, s. 195. Dariusz Szenkowski opowiada się za bezwzględnym nagrywaniem wysłuchania dziecka $\mathrm{z}$ uwagi na nierzetelność tych czynności procesowych. D. Szenkowski, Zasada fair trial w kontekście prawa do obrony i kontroli instancyjnej 
Notatka ta powinna obejmować wnioski z rozmowy, które nie odnoszą się do szczegółów wypowiedzi dziecka, mogących wikłać je w konflikt rodzinny. Wnioski te mogą być udostępnione stronom.

\section{Wysłuchanie małoletniego - kwestie organizacyjne}

Z perspektywy psychologicznej wysłuchanie to szczególna forma relacji interpersonalnej, której specyfika polega na braku równowagi między rozmówcami ${ }^{32}$. Przygotowanie dziecka do udziału w wysłuchaniu może być istotnym elementem jego ochrony przed stresem wynikającym z udziału w sprawie ${ }^{33}$. Dla ochrony małoletniego istotną kwestią jest wybór momentu wysłuchania. Zbyt wczesny kontakt z dzieckiem powoduje, że sędzia nie wie, jakie kwestie będą wymagały wyjaśnienia. Wysłuchanie w końcowym etapie postępowania może natomiast prowadzić do obciążenia małoletniego odpowiedzialnością za rozstrzygnięcie. Data wysłuchania dziecka każdorazowo powinna być ustalona poza terminem rozprawy, aby uniknąć dodatkowych obciążeń małoletniego w postaci oczekiwania na rozprawę, oraz tak, aby sędzia miał możliwość przygotowania się do rozmowy $z$ dzieckiem ${ }^{34}$.

Właściwie przeprowadzone wysłuchanie nie tylko daje szansę na ochronę dziecka przez wydanie zgodnego z jego interesem orzeczenia, ale również pokazuje dziecku, że ma prawo wyrażać swoje potrzeby ${ }^{35}$. W celu prawidłowego przeprowadzenia wysłuchania formułuje się szereg zasad jego realizacji, wśród

w postępowaniu przed sadem II instancji na przykładzie spraw rodzinnych i opiekuńczych $w$ Polsce [w:] Postępowanie cywilne - wprowadzone i projektowane zmiany 2019, red. G. Jędrejek, S. Kotas, F. Manikowski, Warszawa 2019, s. 395. Do stanowiska autora należy odnieść się sceptycznie, po pierwsze dlatego, że nagrywanie dziecka może narazić go na dodatkowy i niepotrzebny stres, a po drugie z tego powodu, że w obowiązującym stanie prawnym brakuje do tego podstaw prawnych.

32 A. Budzyńska, Wystuchanie dziecka w postępowaniu cywilnym - perspektywa psychologiczna, „Dziecko Krzywdzone. Teoria, Badania, Praktyka” 2015, nr 4, s. 35. Autorka zaznacza, że problemem jest brak jasnych procedur przeprowadzenia wysłuchania. Wywiady z sędziami i badania aktowe wskazują na zróżnicowanie w zakresie warunków, sposobu rejestracji i zasad wysłuchania.

33 Przygotowanie dziecka należy odróżnić od przygotowania samego wysłuchania (tj. od podjęcia decyzji o jego zasadności), dla którego najlepszym narzędziem może być przeprowadzony uprzednio wywiad środowiskowy. Pomocne mogą być też zaświadczenia lekarskie i opinie z placówki edukacyjnej.

34 A. Budzyńska, op. cit., s. 45.

35 Joanna Bodio zaznacza, że wysłuchanie małoletniego ma cel wychowawczy polegający na wyrobieniu u dziecka poczucia współodpowiedzialności za decydowanie o jego sprawach, a także na podkreśleniu, że dziecko jest centralną postacią postępowania. J. Bodio, op. cit., s. 415. 
których wymienia się: przeprowadzenie czynności wysłuchania w warunkach sprzyjających swobodzie wypowiedzi ${ }^{36}$; nawiązanie z dzieckiem kontaktu i prowadzenie rozmowy w sposób odpowiadający jego możliwościom rozwojowym; minimalizowanie możliwości obciążania dziecka za rozstrzygnięcia sądu i zachowanie procedury zgodnej ze standardami ${ }^{37}$.

Odpowiednie wysłuchanie małoletniego jest bardzo istotne, ponieważ wartość informacji uzyskanych od dziecka jest uzależniona od wielu czynników. Jest uwarunkowana nie tylko indywidualnymi możliwościami dziecka oraz jego środowiskiem rodzinnym, ale również sposobem prowadzenia czynności procesowej oraz wiedzą, doświadczeniem i umiejętnościami interpersonalnymi wysłuchującego ${ }^{38}$. Dostosowanie warunków wysłuchania dziecka do jego rozwoju może okazać się środkiem do uzyskania rzetelnych i wiarygodnych informacji, a prawo dziecka do wypowiedzi może być wtedy w pełni zrealizowane $e^{39}$.

W literaturze zauważa się też, że jeżeli dziecko przedstawia swoje zdanie w sposób rozsądny, a jego rozwój umysłowy, stan zdrowia i stopień dojrzałości pozwalają sądowi na poważną ocenę poglądu małoletniego, wówczas inne dowody przeprowadzone w sprawie mogą mieć drugorzędne znacznie. Niemniej jednak akcentuje się, że znaczna część tych środków dowodowych może mieć za przedmiot sytuację opiekuńczo-wychowawczą dziecka, a więc sąd, który bierze pod uwagę te inne dowody, nie jest związany wyłącznie zdaniem małoletniego ${ }^{40}$.

Inną kwestią jest ewentualne ponawianie wysłuchania dziecka. Na ten temat wypowiada się Jerzy Słyk ${ }^{41}$, który stwierdza, że jest ono niedopuszczalne, co uzasadnia charakterem tej czynności oraz potrzebą ochrony dobra dziecka, które mogłoby ucierpieć wskutek wielokrotnego wzywania do sądu oraz ponawiania pytań. Autor zaznacza jednak, że brakuje formalnych przesłanek wyłączających ponowienie wysłuchania, co sprawia, że w wyjątkowych przypadkach jest ono dozwolone. Pogląd autora należy podzielić.

W konkluzji trzeba zaznaczyć, że dziecko powinno być informowane o celu i skutkach wysłuchania w sposób odpowiadający jego dojrzałości i że może ono odmówić przeprowadzenia z nim tej czynności. Wysłuchania dziecka należy dokonywać wyłącznie po spełnieniu określonych przesłanek (względna obligatoryjność), bacząc, by wysłuchanie, które ma służyć dobru dziecka, paradoksalnie nie doprowadziło do naruszenia tego dobra. Należy przyjąć, że wysłuchanie jest konieczne, jeśli: sprawa dotyczy interesów dziecka, dziecko ma rozeznanie co do charakteru sprawy, jego rozwój umysłowy, stan zdrowia i stopień dojrzałości

36 Szerzej o warunkach wysłuchania zob. A. Czerederecka, Psychologiczne, op. cit., s. 41.

37 A. Budzyńska, op. cit., s. 42.

38 K. Borkowska, Prawo dziecka do wypowiedzi w sprawach rozpoznawanych przez sad rodzinny, Warszawa 2014, s. 34.

39 Ibidem, s. 46.

40 M. Cieśliński, Wystuchanie, op. cit., s. 64.

41 J. Słyk, op. cit., s. 27. 
umożliwiają wysłuchanie i wysłuchanie to nie jest sprzeczne z dobrem dziecka. Nie oznacza to jednak, że dziecko należy wysłuchać w każdym wypadku osobiście i bezpośrednio przed sądem. Kierując się celowością, przy uwzględnieniu stopnia dojrzałości małoletniego oraz charakteru sprawy sąd powinien zapoznać się ze stanowiskiem małoletniego, mając na względzie jego dobro ${ }^{42}$. Jeśli sąd decyduje się nie wysłuchiwać dziecka, powinien to uzasadnić ${ }^{43}$. Należy też zwrócić uwagę na fakt, że sąd może pominąć wysłuchanie małoletniego zawsze, jeżeli czynność ta spowoduje przewlekłość postępowania. Przeciwko obligatoryjności stosowania art. $216^{1}$ k.p.c. przemawia także wykładnia systemowa, gdyż małoletni nie może mieć więcej uprawnień procesowych niż strona pełnoletnia, w której przypadku zarówno wysłuchanie informacyjne (art. 216 k.p.c.), jak i przeprowadzenie dowodu z przesłuchania strony ustawodawca pozostawił ocenie sądu $(\text { art. } 299 \text { k.p.c. })^{44}$.

\section{Wysłuchanie małoletniego w rządowym projekcie nowelizacji Kodeksu rodzinnego i opiekuńczego z 2019 r.}

W rządowym projekcie nowelizacji Kodeksu rodzinnego i opiekuńczego z 2019 r. planowano dodanie w art. $216^{1}$ k.p.c. $\$ 3$ (analogicznie w art. 576 k.p.c.), zgodnie z którym jeżeli wysłuchanie małoletniego odbywa się na terenie sądu lub prokuratury, przeprowadza się je w odpowiednio przystosowanych przyjaznych pomieszczeniach, zapewniających dziecku swobodę wypowiedzi i poczucie bezpieczeństwa. Zmiana w tym zakresie wynika $\mathrm{z}$ potrzeby ustandaryzowania warunków, w których może odbywać się wysłuchanie małoletnich. Obecnie obowiązująca regulacja normuje jedynie, że wysłuchanie odbywa się poza salą posiedzeń sądu. Przepis miał zostać uzupełniony o warunki, jakie powinno spełniać takie pomieszczenie. Jak wynika $\mathrm{z}$ uzasadnienia projektu, celem proponowanej zmiany było to, aby pokoje wysłuchań miały przyjazne dla małoletnich

42 Postanowienie SN z dnia 15 grudnia 1998 r., I CKN 1122/98, OSNC 1999, nr 6, poz. 119.

43 Zob. postanowienie SN z dnia 22 czerwca 2012 r., V CSK 283/11, LEX nr 1232479, Legalis nr 544269.

44 P. Telenga, op. cit., s. 400, nb. 3. Autor zaznacza, że samo tylko zaniechanie wysłuchania małoletniego ani nie prowadzi do nieważności postępowania cywilnego z powodu pozbawienia możności obrony praw małoletniego (art. 379 pkt 5 k.p.c.), ani nie uzasadnia skargi o wznowienie postępowania cywilnego na podstawie art. 401 pkt 2 k.p.c., jeżeli małoletni składa oświadczenia procesowe za pośrednictwem swojego przedstawiciela ustawowego lub pełnomocnika należycie ustanowionego przez przedstawiciela ustawowego. Z uzasadnienia orzeczenia powinno wynikać, czy wysłuchanie dziecka było podstawą poczynienia ustaleń faktycznych, czy też jedynie sposobem poznania stanowiska małoletniego. 
wnętrze. Nie byłoby wymagane instalowanie w pomieszczeniach sprzętów rejestrujących obraz i dźwięk, gdyż wysłuchanie nie podlega ujawnieniu. Jednocześnie podkreślono, że jeżeli sądy już posiadają pomieszczenia spełniające pełne wymagania określone w obowiązujących przepisach, to w takich pomieszczeniach również mogą odbywać się wysłuchania małoletnich.

Proponowana regulacja zasługuje na aprobatę, niemniej jednak jest fragmentaryczna, dlatego też warto dodatkowo rozważyć bardziej kompleksowe uregulowanie wysłuchania dziecka, określające nie tylko warunki jego przeprowadzenia, ale także osoby, które je przeprowadzają (np. przewodniczący składu orzekającego z wyłączeniem ławników w sądzie pierwszej instancji lub wyznaczony sędzia w sądzie drugiej instancji), oraz status tej czynności w postępowaniu dowodowym. Nowelizacja powinna również wprost określić rolę, jaką w wysłuchaniu dziecka powinien odgrywać psycholog.

\section{Wysłuchanie małoletniego w projekcie Rzecznika Praw Dziecka z 2018 r.}

Bardziej kompleksowe ujęcie wysłuchania małoletniego zostało zaproponowane w projekcie Kodeksu rodzinnego z lipca 2018 r. ${ }^{45}$ przedstawionym przez Rzecznika Praw Dziecka (dalej: projekt RPD z 2018 r.) ${ }^{46}$. Projekt ten nie trafił do Sejmu, jednak zawiera wiele propozycji, które mogłyby zostać uwzględnione w ramach nowelizacji przepisów o wysłuchaniu małoletniego.

We wskazanym projekcie wysłuchanie dziecka jest jedną z zasad prawa rodzinnego. Projektowany art. 10 tego aktu stanowi, że w każdej sprawie dotyczącej dziecka rodzice, inne osoby ponoszące taką odpowiedzialność jak rodzice oraz organy władzy publicznej mają obowiązek wysłuchania go, umożliwienia dziecku swobodnego wypowiedzenia się we wszystkich kwestiach dotyczących jego osoby i majątku, w tym związanych $\mathrm{z}$ jego sytuacją rodzinną i społeczną. W projekcie znalazła się też definicja takiego wysłuchania. Zgodnie z art. 21 pkt 27 projektu wysłuchanie dziecka to umożliwienie dziecku swobodnego wyrażenia myśli, uczuć, woli w sprawach jego dotyczących, przy zachowaniu metod odpowiednich do wieku i rozwoju dziecka, w warunkach przyjaznych oraz zabezpieczających jego dobro.

45 Projekt jest efektem prac Komisji Kodyfikacyjnej Prawa Rodzinnego, utworzonej w lipcu 2012 r. Członkami komisji zostali m.in.: W. Stojanowska, S. Kalus, J. Słyk, H. Ciepła, B. Czech, P. Jaros i J. Ignaczewski. Zob. też ocenę projektu M. Nazar, Projekt kodeksu rodzinnego i postulaty gatęziowego wyodrębnienia prawa rodzinnego, „Przegląd Sądowy” 2019, nr 7-8, s. 10.

46 http://brpd.gov.pl/sites/default/files/kodeks_rodzinny_projekt_z_uzasadnieniem.pdf [dostęp 1 lutego 2020 r.]. 
Zgodnie z art. 299 projektu RPD z 2018 r. sąd „wysłucha dziecko w sprawach dotyczących jego osoby lub majątku”, a „stosownie do okoliczności, rozwoju intelektualnego, społecznego i psychicznego, oraz stanu zdrowia dziecka uwzględni jego stanowisko i rozsądne życzenia”. „W wysłuchaniu dziecka powinien uczestniczyć biegły psycholog lub inny specjalista” (\$3). „Sąd wysłuchuje dziecko tylko raz, chyba że ochrona praw i dobra dziecka wymaga ponownego wysłuchania” (\$ 4). W art. $300 \$ 1$ projektu RPD z 2018 r. przyjęto: „Wysłuchanie dziecka odbywa się bez obecności stron, uczestników postępowania, ich pełnomocników, poza salą posiedzeń sądowych, w pomieszczeniu przyjaznym dziecku, w sposób zapewniający mu pełną swobodę wypowiedzi, a w uzasadnionych przypadkach w jego miejscu zwykłego pobytu”. „Czynność wysłuchania utrwala się na nośnikach utrwalających dźwięk i obraz oraz sporządza się notatkę. W przypadku niemożności utrwalenia wysłuchania na nośniku, z wysłuchania sędzia sporządza notatkę. Zapisu dźwięku i obrazu z wysłuchania dziecka oraz treści notatki nie udostępnia się uczestnikom i stronom postępowania oraz ich pełnomocnikom" $(\$ 2)$. W kolejnych paragrafach przyjęto: „Planowana pora i czas wysłuchania powinny uwzględniać potrzeby wynikające $\mathrm{z}$ wieku dziecka, nawiązania $\mathrm{z}$ nim kontaktu przez biegłego psychologa lub innego specjalistę przed przystąpieniem do wysłuchania oraz ewentualnych przerw w prowadzeniu tej czynności”, „Przed rozpoczęciem wysłuchania, stosownie do okoliczności, sędzia ma poinformować dziecko o znaczeniu i sposobie prowadzenia wysłuchania”. Zgodnie z art. $300 \$ 5$ omawianego projektu: „Przed rozpoczęciem wysłuchania biegły psycholog lub inny specjalista może przeprowadzić z dzieckiem wstępną rozmowę w celu obniżenia poziomu lęku i niepokoju dziecka; może także w miarę potrzeby udzielić sędziemu pomocy w wyjaśnieniu w sposób zrozumiały dla dziecka zasad wysłuchania, w tym obowiązku mówienia prawdy, utrwalania czynności w formie zapisu na nośnikach oraz prawa dziecka do odmowy wysłuchania”. „Jeżeli dziecko jest osobą z niepełnosprawnością, biegły psycholog lub inny specjalista udziela sędziemu pomocy", o której mowa wyżej (\$6).

Celem projektu RPD z 2018 r. było nadanie odpowiedniej rangi ustawowej czynności wysłuchania dziecka poprzez dopracowanie zasad wysłuchania dziecka. Między innymi przesądzono o konieczności obecności biegłego psychologa podczas wysłuchania i przyjęto zasadę, że sąd wysłuchuje dziecko tylko raz, co zasługuje na aprobatę. Ponadto doprecyzowano, że czynność wysłuchania zapisuje się na nośnikach utrwalających dźwięk i obraz oraz sporządza się notatkę, co jednak wydaje się wątpliwe w związku z narażaniem dziecka na dodatkowy stres. Inną wątpliwą kwestią jest to, że zapisu dźwięku i obrazu z wysłuchania dziecka oraz treści notatki nie udostępnia się uczestnikom i stronom postępowania oraz ich pełnomocnikom. O ile rozwiązanie to należy uznać za słuszne, o tyle jednak nie wiadomo, czy projektodawca świadomie pominął przy tym sąd drugiej instancji, a co za tym idzie - czy taki zapis byłby dla tego sądu dostępny. Należałoby wyraźnie wskazać, kto ma dostęp do tego zapisu oraz - ewentualnie - co należy 
z nim zrobić w sytuacji, gdy np. pełnomocnicy stron zwracają się o udostępnienie akt sprawy w czytelni sądu.

W projekcie RPD z 2018 r. położono nacisk na podmiotowość dziecka. Przykładowo projektowany art. 112 stanowi, że dziecko ma prawo do szczególnej troski i pomocy oraz ochrony swoich praw i wolności. Dziecko ma także wynikające z tych przepisów obowiązki. O podmiotowości dziecka w postępowaniu sądowym świadczy także to, że dziecku nadaje się status uczestnika postępowania. $\mathrm{W}$ odniesieniu do łączącego się z tym zagadnieniem wysłuchania uregulowano warunki, w jakich wysłuchanie dziecka ma miejsce. Warunki te muszą zagwarantować, że czynność wysłuchania będzie prowadzona zgodnie z dobrem dziecka i że nie naruszy jego praw. Przewidziano wydanie aktu wykonawczego określającego sposób przygotowania wysłuchania dziecka oraz warunki, jakim powinny odpowiadać pomieszczenia przeznaczone do przeprowadzania wysłuchania (art. $300 \$ 7$ projektu RPD z 2018 r.).

\section{Podsumowanie}

Obowiązujące przepisy dotyczące wysłuchania małoletniego dziecka należy uznać za niekompletne. Konieczne jest precyzyjne określenie, kto przeprowadza wysłuchanie - czy jest to sąd w pełnym składzie, czy też przewodniczący składu (jeśli chodzi o postępowanie rozwodowe lub odwoławcze). Ponadto wymagane jest doprecyzowanie, że wysłuchanie dziecka, co do zasady, jest dozwolone tylko jednokrotnie, z ewentualnym wskazaniem, że takie wysłuchanie dopuszczalne jest również w postępowaniu odwoławczym. Przepisy nie nakładają na sąd obowiązku przeprowadzenia wysłuchania małoletniego z udziałem psychologa. Obecność takiego specjalisty jest jednak pożądana. Psycholog może ocenić, czy rozwój emocjonalny dziecka pozwala na przeprowadzenie jego wysłuchania, a także pomóc w odpowiednim formułowaniu pytań kierowanych do dziecka oraz wesprzeć małoletniego w trudnej dla niego sytuacji. Udział psychologa w wysłuchaniu małoletniego został przewidziany w projekcie RPD z 2018 r., w którym zaakcentowano jego szczególną rolę w tej czynności. W związku z tym, że projekt ten nie trafił do Sejmu, w ramach planowanej nowelizacji Kodeksu rodzinnego i opiekuńczego należy postulować uwzględnienie niektórych propozycji w nim zawartych. Przed rozpoczęciem wysłuchania małoletniego psycholog powinien mieć możliwość przeprowadzenia z dzieckiem wstępnej rozmowy w celu obniżenia poziomu jego lęku. Ponadto powinien mieć możliwość udzielenia sędziemu pomocy w wyjaśnieniu w sposób zrozumiały dla dziecka zasad wysłuchania, w tym np. obowiązku mówienia prawdy oraz prawa dziecka do odmowy wysłuchania.

Analiza obowiązujących i projektowanych rozwiązań skłania także do przedstawienia propozycji wprowadzenia wysłuchania dziecka po określonym czasie 
od uprawomocnienia się orzeczenia o rozwiązaniu małżeństwa lub orzeczenia dotyczącego kontaktów. Najczęściej bowiem do pominięcia prymatu dobra dziecka dochodzi przy ich regulowaniu, a zwłaszcza gdy sąd na zgodny wniosek stron nie orzeka o utrzymywaniu kontaktów z dzieckiem bądź w szerokim zakresie uwzględnia kontakty dziecka $\mathrm{z}$ innymi osobami bliskimi niż rodzice. Założeniem proponowanej zmiany byłaby więc weryfikacja sytuacji małoletniego, w szczególności tego, czy kontakty są prawidłowo realizowane i czy odpowiadają dziecku.

\section{Bibliografia}

Bodio J., Status dziecka jako uczestnika postępowania nieprocesowego, Warszawa 2019.

Borkowska K., Prawo dziecka do wypowiedzi w prawie międzynarodowym i krajowym, „Rodzina i Prawo” 2011, nr 19.

Borkowska K., Prawo dziecka do wypowiedzi w sprawach rozpoznawanych przez sąd rodzinny, Warszawa 2014.

Budzyńska A., Wysłuchanie dziecka w postępowaniu cywilnym - perspektywa psychologiczna, „Dziecko Krzywdzone. Teoria, Badania, Praktyka” 2015, nr 4.

Burdziej S., Badanie idei przyjaznego wystuchania dziecka - raport $z$ analizy wywiadów pogłębionych. Opracowanie czastkowe w ramach projektu prowadzonego przez Instytut Wymiaru Sprawiedliwości pt. „Praktyka sądowa w zakresie wysłuchiwania małoletnich $w$ postępowaniach cywilnych $w$ kontekście idei przyjaznego wystuchiwania dziecka", Warszawa 2015.

Ciepła H., Nowelizacje Kodeksu rodzinnego i opiekuńczego z komentarzem, Warszawa 2010. Cieśliński M., Praktyka sądowa wysłuchiwania małoletnich w postępowaniach cywilnych w kontekście idei przyjaznego wysłuchiwania dziecka (komunikat o wynikach badania), „Prawo w Działaniu” 2015, nr 24.

Cieśliński M., Stanowisko sędziów na temat wysłuchania małoletnich w postępowaniu cywilnym, „Prawo w Działaniu” 2017, nr 29.

Cieśliński M., Wystuchanie dziecka w procesie cywilnym (art. $216^{1}$ k.p.c.), „Przegląd Sądowy" 2012, nr 6.

Czerederecka A. [w:] Problemy jednostki i rodziny w obszarze stosowania prawa. Aspekty psychologiczne, red. D. Rode, Warszawa 2016.

Czerederecka A., Psychologiczne kryteria wystuchania dziecka $w$ sprawach rodzinnych i opiekuńczych, „Rodzina i Prawo” 2010, nr 14-15.

Domański M., Orzekanie o pieczy naprzemiennej w wyrokach rozwodowych, „Prawo w Działaniu" 2016, nr 25.

Flaga-Gieruszyńska K., Ochrona dobra dziecka w postępowaniu odrębnym w sprawach małżeńskich [w:] Ochrona strony słabszej stosunku prawnego. Ksiega jubileuszowa ofiarowana Profesorowi Adamowi Zielińskiemu, red. M. Boratyńska, Warszawa 2016.

Ignaczewski J. [w:] Władza rodzicielska i kontakty $z$ dzieckiem, red. J. Ignaczewski, Warszawa 2019. 
Kallaus A., Udział osoby małoletniej w postępowaniu opiekuńczym, Poznań 2015.

Kodeks postępowania cywilnego. Komentarz, red. K. Flaga-Gieruszyńska, A. Zieliński, Warszawa 2019.

Kodeks postępowania cywilnego. Komentarz. Art. 1-729, t. I, red. A. Góra-Błaszczykowska, Warszawa 2013.

Kodeks postępowania cywilnego. Komentarz do art. 1-729, t. I, red. A. Jakubecki, Warszawa 2017.

Kodeks rodzinny i opiekuńczy. Komentarz, t. V, red. K. Osajda, Warszawa 2017.

Kołodziejski S., Dobro wspólnych małoletnich dzieci - jako przesłanka odmowy orzeczenia rozwodu, „Palestra” 1965, nr 9.

Leksykon ochrony praw człowieka. 100 podstawowych pojęć, red. M. Balcerzak, S. Sykuna, Warszawa 2010.

Łapiński A., Ograniczenia władzy rodzicielskiej w polskim prawie rodzinnym, Warszawa 1975.

Łopatka A., Dziecko - jego prawa człowieka, Warszawa 2000.

Nazar M., Projekt kodeksu rodzinnego i postulaty gałęziowego wyodrębnienia prawa rodzinnego, „Przegląd Sądowy” 2019, nr 7-8.

Nowelizacja prawa rodzinnego na podstawie ustaw z 6 listopada 2008 r. i 10 czerwca 2010 r. Analiza. Wykładnia. Komentarz, red. W. Stojanowska, Warszawa 2011.

Olejniczak A., Materialnoprawne przesłanki udzielenia rozwodu, Poznań 1980.

Plewka J., Instytucja wystuchania małoletniego $w$ świetle unormowań prawnych kodeksu postępowania cywilnego [w:] Tendencje prawa materialnego i procesowego cywilnego, red. E. Marszałkowska-Krześ, Wrocław 2017.

Radwański Z., Pojęcie i funkcja „dobra dziecka” w polskim prawie rodzinnym i opiekuńczym, „Studia Cywilistyczne” 1981, t. XXXI.

Słyk J., Aspekty prawne wysłuchania dziecka w postępowaniu cywilnym, „Dziecko Krzywdzone. Teoria, Badania, Praktyka" 2015, nr 4.

Stojanowska W., Rozwód a dobro dziecka, Warszawa 1979.

Szenkowski D., Zasada fair trial w kontekście prawa do obrony i kontroli instancyjnej w postępowaniu przed sadem II instancji na przykładzie spraw rodzinnych i opiekuńczych $w$ Polsce [w:] Postępowanie cywilne - wprowadzone i projektowane zmiany 2019, red. G. Jędrejek, S. Kotas, F. Manikowski, Warszawa 2019.

Zajączkowska J., Głos dziecka na wokandzie - o instytucji wysłuchania małoletniego, „Palestra" 2013, nr 7-8.

Zegadło R., Dziecko w postępowaniach sq̨dowych i administracyjnych, „Rodzina i Prawo” 2011, nr 19. 